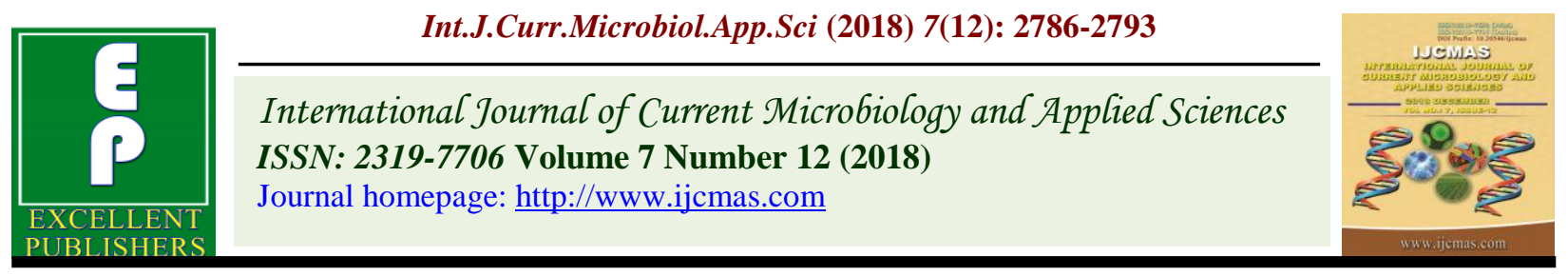

Original Research Article

https://doi.org/10.20546/ijcmas.2018.712.316

\title{
Anti-cancerous Activities of Anthocyanins of Banana cv. Nendran (Musa sp.) Flower Bracts against Human Colon and Cervical Cancer Cell Lines
}

\author{
R. Suman ${ }^{1}$, K. Kalaimathi ${ }^{1}$, S. Palanichamy ${ }^{2}$, R. Sowmiya ${ }^{2}$, \\ M. Mayil Vaganan ${ }^{2}$, I. $\operatorname{Ravi}^{2}$ and S. Uma \\ ${ }^{l}$ Dr. N.G.P. Arts and Science College, Kalapatty, Coimbatore, Tamil Nadu, India \\ ${ }^{2}$ ICAR-National Research Centre for Banana, Thogamalai Road, Thayanur Post, \\ Tiruchirappalli, Tamil Nadu, India \\ *Corresponding author:
}

A B S T R A C T

Keywords

Banana bracts,

Anthocyanins,

Colorectal cancer,

Cervical cancer, MTT

assay

Article Info

Accepted:

20 November 2018

Available Online:

10 December 2018

\begin{abstract}
A comparative study on the anticancer effects of anthocyanins derived from banana cv. Nendran flower bracts against human colon (HT-29) and cervical cancer (HeLa) cells were investigated. In vitro assays by MTT, $\mathrm{AO} / \mathrm{EtBr}$ and MMP revealed that anthocyanins extract inhibited the growth of both HT-29 and HeLa cells. The percentage of cell viability decreased linearly with increment of anthocyanins. The $\mathrm{IC}_{50}$ values for anthocyanins were $41.18 \mu \mathrm{g} / \mathrm{ml}$ for colon cancer cells and $46.50 \mu \mathrm{g} / \mathrm{ml}$ for the cervical cancer cells by MTT assay. The MMP assay indicated $\mathrm{IC}_{50}$ values of 71.18 and $106.5 \mu \mathrm{g} / \mathrm{ml}$ respectively for HT-29 cells and HeLa cells. The study demonstrates that anthocyanins of banana flower bracts are potential anticancerous compounds.
\end{abstract}

\section{Introduction}

Anthocyanins are water-soluble pigments providing a vast range of colours from red to blue in flowers, fruits, leaves and storage organs of many plants (Pervaiz et al., 2017) and belong to the large phenolic family known as flavonoids. Due to electron deficiency, they are highly active towards reactive oxygen species (ROS) and have free radical scavenging and antioxidative properties. Numerous structures of anthocyanins have been reported across plant species (Gollop et al., 2002). Considered as natural antioxidants, these compounds reduce oxidative stress and prevent cancers and heart diseases. One the major functions of anthocyanins are fortification against DNA injury and capable of detaining hazardous free radicals as singlet oxygen $\left({ }^{1} \mathrm{O}_{2}\right)$, superoxide radical $\left(\mathrm{O}_{2}{ }^{-}\right)$, hydroxyl radical (HO) and hydrogen peroxide $\left(\mathrm{H}_{2} \mathrm{O}_{2}\right)$ (Oancea et al., 2011). Banana flowers are abundantly available agro-waste in banana production and bracts of flowers are a rich 
source of anthocyanin pigments. The yield of anthocyanins from bracts of various banana cultivars ranges from 50 to $350 \mathrm{mg}$ per $100 \mathrm{~g}$ on fresh weight basis, which is several times higher than commercially used red cabbage.

Cancer is a disease in which abnormal cells divide without control and are able to invade other tissues. There is a wide range of factors, which directly causes cancer and/or contributes to the risk of developing cancer and its associated health issues. Cancers development is in three stages namely initiation, promotion and progression and ROS act as inducers in all these stages of cancers (Klaunig and Kamendulis, 2004). Free radicals are known to react with all components of DNA, thus damaging its bases and the deoxyribose backbone causing mutations in crucial genes, which may lead to cancer (Ames and Shigenaga, 1992). Apoptosis or programmed cell death plays a key role in the development and growth regulation of normal cells and it is deregulated in cancer cells. Anthocyanins, as effective chemopreventive agents, are strong inducers of apoptosis in premalignant and malignant cells. Previous in vitro studies showed that pure anthocyanins and anthocyanin-rich extracts from fruits and vegetables have exhibited antiproliferative activity towards multiple cancer cell types (Rodrigo et al., 2006). Many other studies demonstrated that anthocyanin-rich extracts from berries and grapes and several pure anthocyanins and anthocyanidins have exhibited pro-apoptotic effects in multiple cell types (Olsson et al., 2004). Anthocyanins induce apoptosis through both intrinsic (mitochondrial) and extrinsic (FAS) pathways (Reddivari et al., 2007). Cervical and colorectal cancers are the second and third most common human ailments with more than half a million new cases diagnosed reported every year and are the public health burdens worldwide (Haggar et al., 2009). In the present study, anthocyanins extracted from banana flower bracts were tested in vitro against colon (HT-29) and cervical cancer (HeLa) cell lines and results are presented.

\section{Materials and Methods}

\section{Chemicals}

Dulbecco's Modified Eagle's Medium (DMEM), Fetal Bovine Serum (FBS), Antibiotic solution, Penicillin/Streptomycin antibiotic solution, Trypsin-EDTA were obtained from Gibco (USA), Dimethyl sulfoxide (DMSO), 3(4,5-Dimethylthiazol-2-yl)-2,5-diphenyl tetra zolium bromide (MTT), Ethidium bromide $(\mathrm{EtBr})$ and Acridine orange were obtained from Sigma Aldrich, (USA), Phosphate Buffered Saline (PBS) was sourced from HiMedia, (India). Ninety-six well tissue culture plate and wash beaker were from Tarson, Kolkata, India.

\section{Anthocyanins extract}

Anthocyanins extract was prepared from banana flower bracts cv. Nendran by maceration using $0.3 \%$ acidified methanol. The extract was filtered through Whatman No. 1 filter paper, concentrated using rotary flash evaporator under darkness protecting from light and stored at $2{ }^{\circ} \mathrm{C}$ until analysis.

\section{Cell culture}

Human colon carcinoma (HT-29 cells) and $\mathrm{HeLa}$ cell lines were cultured in liquid medium (D-MEM) supplemented with 10\% fetal bovine serum (FBS), $100 \mathrm{IU} / \mathrm{ml}$ penicillin and $100 \mu \mathrm{g} / \mathrm{ml}$ streptomycin, and maintained under an atmosphere of $5 \% \mathrm{CO}_{2}$ at $37{ }^{\circ} \mathrm{C}$.

\section{MTT assay}

The anthocyanin sample was tested for in vitro cytotoxicity using HT-29 cells and HeLa 
cells by MTT assay following the methodology adopted by Lazze et al., (2004). Briefly, the cultured HT-29 cells were harvested by trypsinization and pooled in a 15 $\mathrm{ml}$ test tube. Then, the cells were plated at a density of $1 \times 10^{5}$ cells $/ \mathrm{ml}$ cells/well $(200 \mu \mathrm{L})$ into 96-well tissue culture plate in D-MEM medium containing $10 \%$ FBS and $1 \%$ antibiotic solution for $48 \mathrm{hr}$ at $37{ }^{\circ} \mathrm{C}$. The wells were washed with sterile PBS and treated with various concentrations of the anthocyanin sample in a serum-free D-MEM medium. Each anthocyanin sample was replicated thrice and the cells were incubated at $37{ }^{\circ} \mathrm{C}$ in a humidified $5 \% \mathrm{CO}_{2}$ incubator for $24 \mathrm{hr}$. After the incubation period, $20 \mu \mathrm{L}$ of 5 $\mathrm{mg} / \mathrm{ml}$ of MTT was added into each well and the cells were incubated for another 2-4 hr until the purple precipitates were visible under an inverted microscope. Finally, the medium together with $220 \mu \mathrm{L}$ of MTT was aspirated off the wells and washed with 1 X PBS (200 $\mu 1)$. Further, $100 \mu \mathrm{L}$ of DMSO was added to dissolve formazan crystals and the plate was shaken for $5 \mathrm{~min}$. The absorbance for each well was measured at $570 \mathrm{~nm}$ using a microplate reader (Thermo Fisher Scientific, USA) and the percentage cell viability and $\mathrm{IC}_{50}$ value was calculated using Graph Pad Prism 6.0 software (USA).

\section{MMP assay}

The HT-29 cells and HeLa cells (5,00020,000 cells/well) were plated to a coverslip containing 24 well plates and incubated for 24 hrs in a DMEM growth medium. After incubation, the plates were washed with PBS (Phosphate buffered saline) and treated with anthocyanin sample in a serum-free DMEM medium. Again, the plate was incubated at 37 ${ }^{\circ} \mathrm{C}$ in a humidified $5 \% \mathrm{CO}_{2}$ incubator for $24 \mathrm{~h}$. The measurement of mitochondrial membrane potential for the treated and control cells was carried out according to the manufacturer's instruction (Ji et al., 2017; Wang and Liu,
2018). Briefly, the cells were incubated with $100 \mu \mathrm{l} /$ well of JC-10 dye loading solution and plate was protected from light. The plate was incubated for 30-60 minutes in a 5\% $\mathrm{CO}_{2}$ incubator at $37{ }^{\circ} \mathrm{C}$. After incubation, 100 $\mu \mathrm{l} /$ well assay buffer was added to each sample/well. Finally, the plate was centrifuged at $800 \mathrm{rpm}$ for 2 minutes and the fluorescence on the coverslip was observed at 490/525 and $540 / 590$ ratio.

\section{Acridine orange/Ethidium bromide assay}

In vitro cytotoxicity of the anthocyanin sample was tested for using HT-29 cells and HeLa cells by $\mathrm{AO} / \mathrm{EtBr}$ staining followed the protocol described by Bouzari et al., (2009). A $5 \times 10^{5}$ cells $/ \mathrm{ml}$ of HT-29 and HeLa cells were seeded into the 24 well tissue culture plates and treated with anthocyanin sample in a serum-free DMEM medium. The plate was incubated at $37{ }^{\circ} \mathrm{C}$ in $5 \% \mathrm{CO}_{2}$ incubator for 24 hr. After incubation, $50 \mu \mathrm{l}$ of $1 \mathrm{mg} / \mathrm{ml}$ Acridine orange and $\mathrm{EtBr}$ were added into the wells and mixed gently. Finally, the plate was centrifuged at $800 \mathrm{rpm}$ for 2 minutes and evaluated immediately within an hour and examined at least 100 cells by fluorescence microscope using a fluorescent filter.

\section{Results and Discussion}

\section{Cell viability}

Cell viability decreased in a dose-dependent manner in both HeLa and HT-29 cell lines treated with anthocyanins extract in comparison to the normal cell (Fig. 1 and 2).

\section{MTT assay}

The formation of formazan crystals in the treated cells depends upon the concentration of the sample. At the lowest concentration of $20 \mu \mathrm{g} / \mathrm{ml}$, most of the cancer cells were viable without showing any notable effect. However, 
at higher concentration $(200 \mu \mathrm{g} / \mathrm{ml}), 55 \%$ of mortality on cancer cells was recorded. The $\mathrm{IC}_{50}$ value for anthocyanins sample concentration was $41.18 \mu \mathrm{g} / \mathrm{ml}$ for colon cancer cells and $46.50 \mu \mathrm{g} / \mathrm{ml}$ for the cervical cancer cells (Fig. 3). Similarly, dose- dependent cytotoxic effect of amberlite XAD7 purified anthocyanins extract from Begonia malabarica and Begonia rex-cultorum 'Baby' Rainbow plants were obtained by MTT assay (Madanakumar and Kumarasamy, 2018).

Fig.1 Percentage of cell viability of HeLa cell line tested against different concentrations of anthocyanins derived from banana cv. Nendran flower bracts

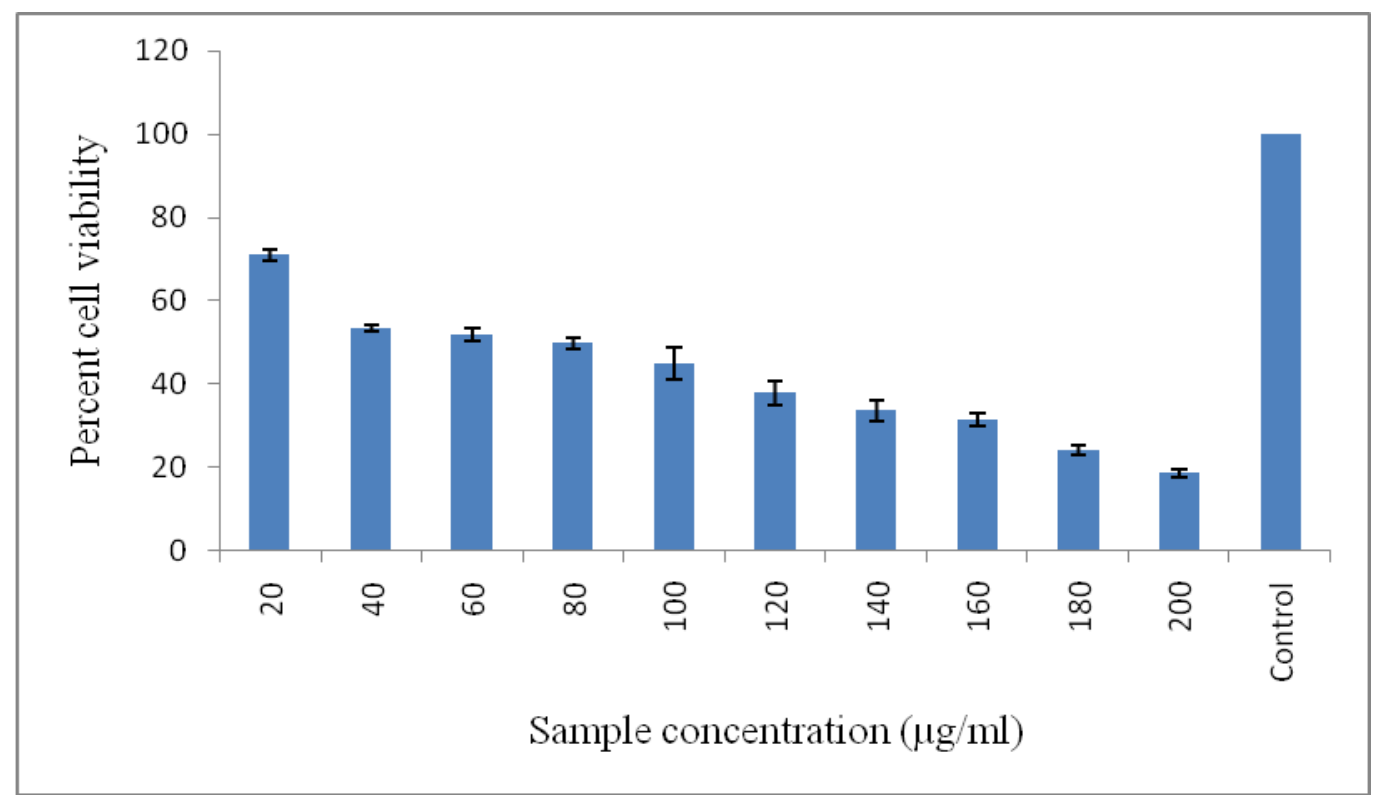

Fig.2 Percentage of Cell viability of HT-29 cell line tested against different concentrations of anthocyanins derived from banana cv. Nendran flower bracts

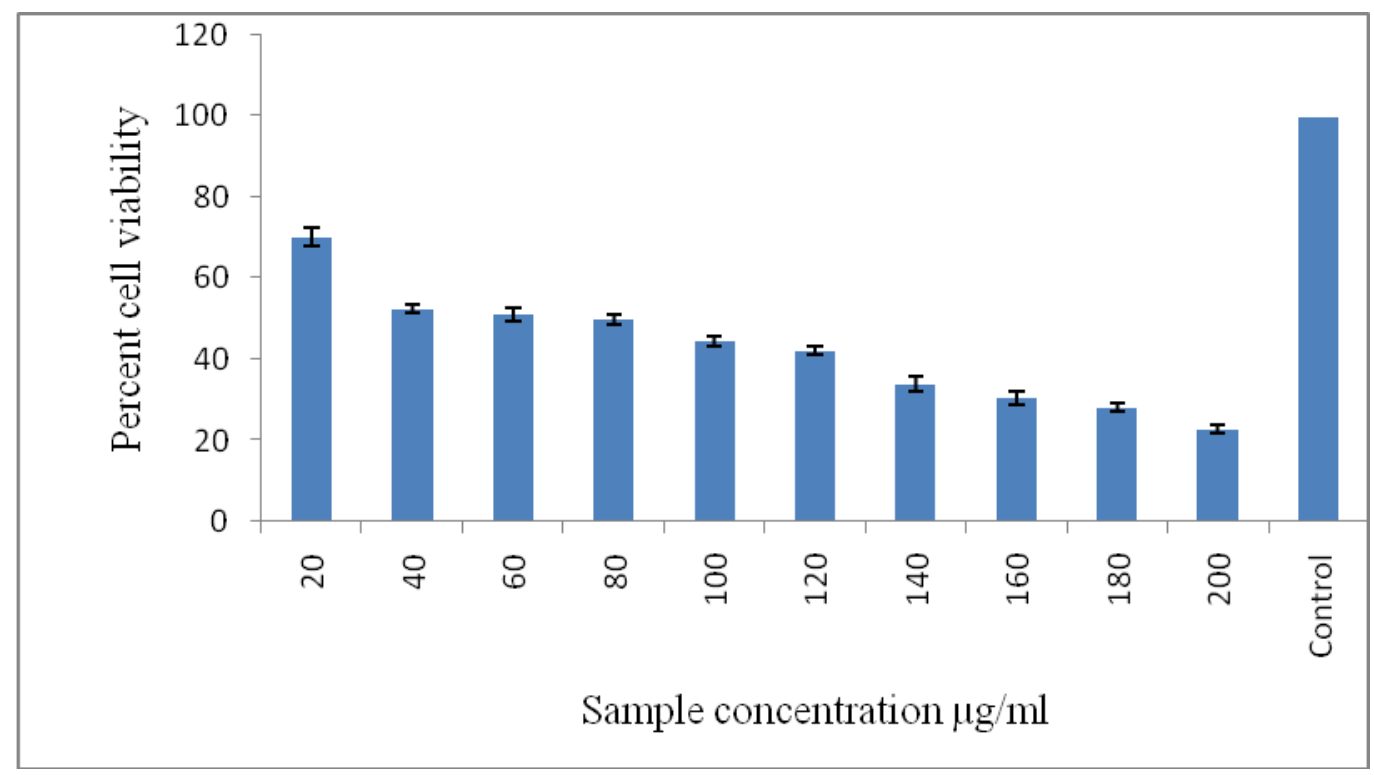


Fig.3 Formation of formazan crystals in the control and sample treated HeLa (top) and HT-29 (bottom) cancer cell lines
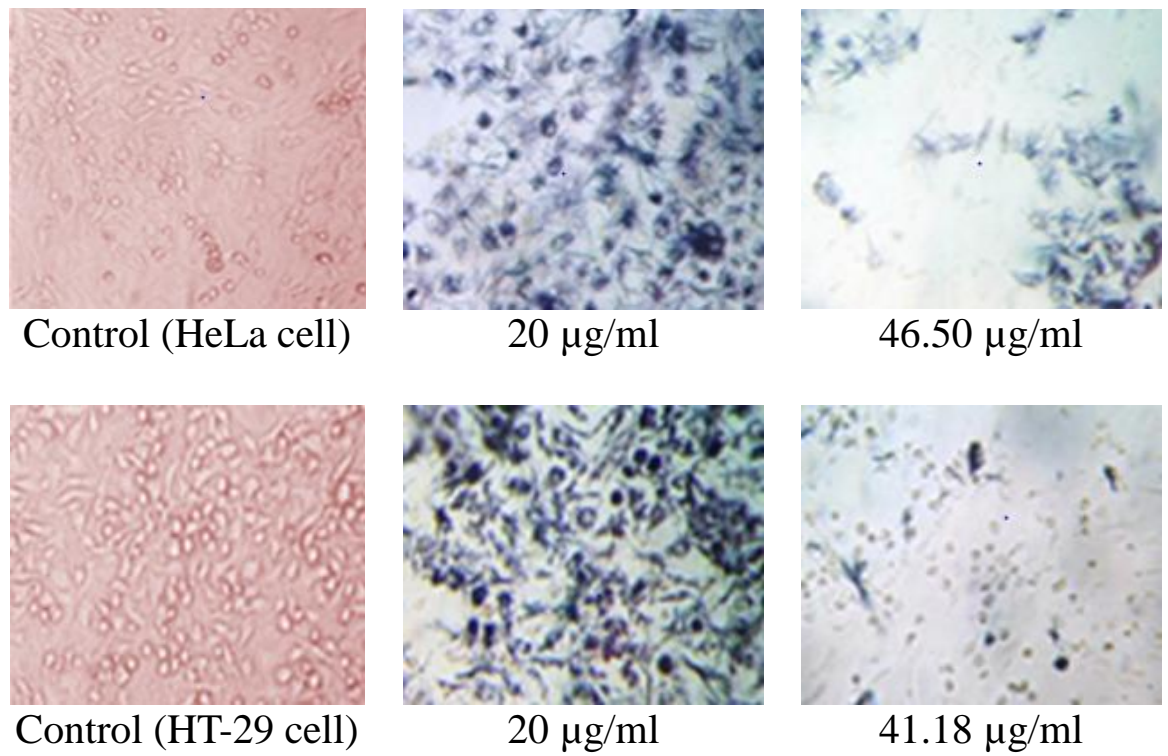

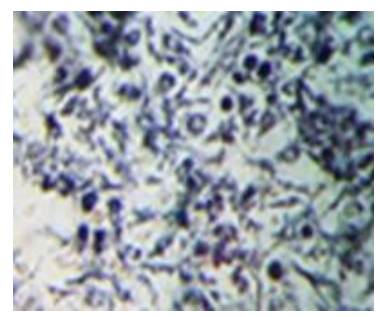

$20 \mu \mathrm{g} / \mathrm{ml}$
$46.50 \mu \mathrm{g} / \mathrm{ml}$

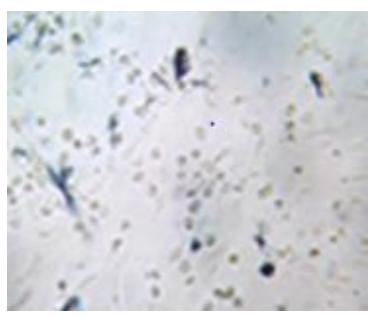

$41.18 \mu \mathrm{g} / \mathrm{ml}$

Fig.4 Green fluorescent cancer cell population after the treatment with JC-10 dye in MMP assay (sample dose in bracket)

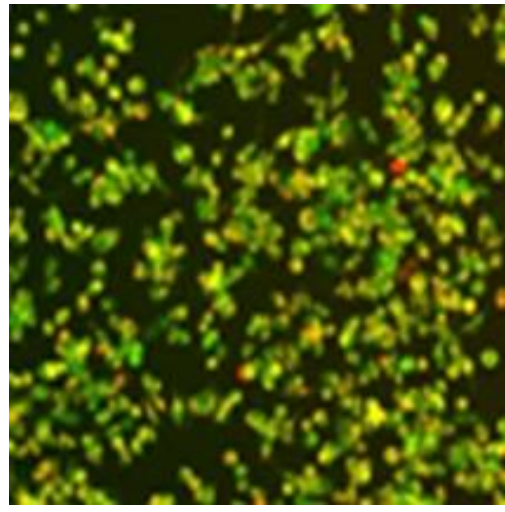

Control (HeLa cell)

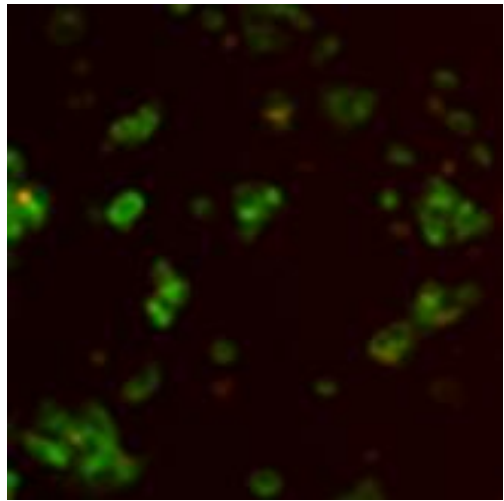

Control (HT-29 cell)

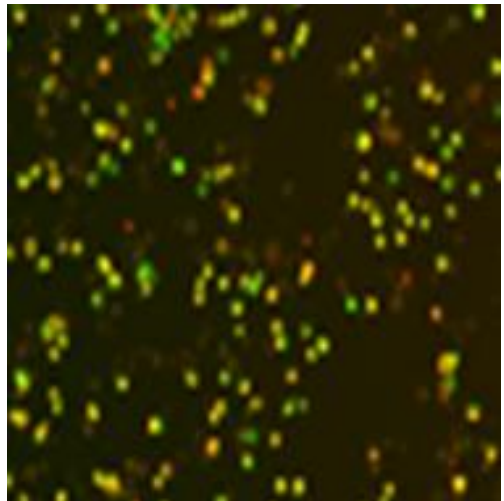

HeLa cell $(106.5 \mu \mathrm{g} / \mathrm{ml})$

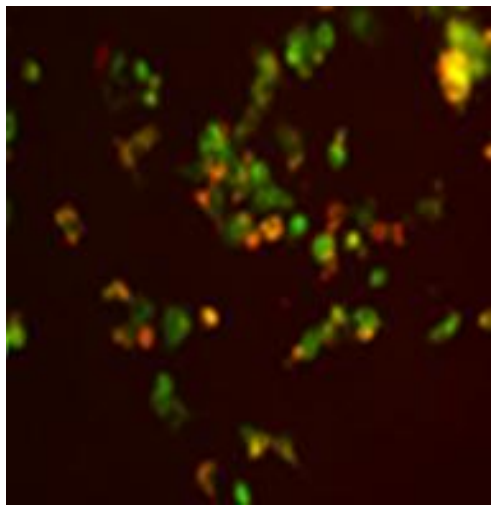

HT-29 cell $(71.18 \mu \mathrm{g} / \mathrm{ml})$ 
The anti-proliferative activity was categorized according to the median inhibitory concentration $\left(\mathrm{IC}_{50}\right)$ into four groups: $\leq 20$ $\mu \mathrm{g} / \mathrm{ml}$, active; >20-100 $\mu \mathrm{g} / \mathrm{ml}$, moderately active; $>100-1000 \mu \mathrm{g} / \mathrm{ml}$, weakly active and $>1000 \mu \mathrm{g} / \mathrm{ml}$, inactive (Atjanasuppat et al., 2009). Accordingly, anthocyanins from banana bract showed moderately active on both HT-29 colon cancer cells and HeLa cervical cancer cells. The two individual aglycone anthocynins, cyaniding and delphidin were used to examine their effects on cell cycle progression and induction of apoptosis on human cancer cell lines, uterine carcinoma and colon adenocarcinoma cells. The clonogenic assay showed that cyaniding induces a dose-dependent growth whereas, delphidin inhibited cell growth in normal as well as tumor cell lines (Lazze et al., 2004).

\section{Mitochondrial membrane potential assay}

The effect of the anthocyanins extract on the cellular morphology of both HeLa and HT-29 cells was studied by mitochondrial membrane potential. The results revealed that the extract exerts antiproliferative effects on both the cell lines. The extract induces cellular shrinkage, chromatin condensation and appearance of apoptosis bodies, which are the hallmarks of cellular apoptosis. The effect was more pronounced in HT-29 cells than HeLa cells (Fig. 4). When treated with the sample concentration of $71.18 \mu \mathrm{g} / \mathrm{ml}, \quad \mathrm{JC}-10$ dye concentrates in the mitochondrial matrix where it forms red fluorescent aggregates by eliminating $50 \%$ of the colorectal cancer cells (HT-29). But, in the case of HeLa cell an increasing concentration of sample (106.5 $\mu \mathrm{g} / \mathrm{ml}$ ) required to replace $50 \%$ of the cervical cancer cells. The purified anthocyanins fractions from chockeberry inhibited the survival of $\mathrm{HeLa}$ cells by $40 \%$ at a concentration of $200 \mu \mathrm{g} / \mathrm{ml}$ after $48 \mathrm{hr}$. Similarly, the survival of HT 29 cell line by $50 \%$ was recorded with $25 \mu \mathrm{g} / \mathrm{ml}$ of cyaniding-3-glucoside/ml after $48 \mathrm{hr}$ exposure (Rugina et al., 2012).

\section{Acridine orange/ethidium bromide assay}

The type of cell death was explored by fluorescence microscopy using the acridine orange/ethidium bromide method. Early-stage apoptotic cells were marked either by a crescent-shaped or granular yellow-green acridine orange nuclear staining whereas, late-stage apoptotic cells were marked with concentrated and asymmetrically localized orange nuclear ethidium bromide staining. Necrotic cells were seen increased in size and showed uneven and orange-red fluorescence at their periphery. These results indicated that anthocyanins treated cell lines exhibit anticarcinogenic activity against colorectal as well as cervical cancer types. The purified anthocyanins from blueberries cultivar Torra showed effective in control of metastatic murine melanoma cell lines B16-F10 (Bunea et al., 2013). The cyaniding based anthocyanins control melanoma cells B16F10 and morphologically confirmed apoptosis as the mechanism for the cell death by acridine orange/ethidium bromide (Rugina et al., 2017). These comprehensive comparative results demonstrated that anthocyanins extract produced the considerable morphological alteration in both the cell lines. Meanwhile, the extract showed a poor cytotoxic effect on normal cells indicating no or fewer side effects. Thus, anthocyanins may be used as a chemo-preventive agent for various cancer cells.

\section{References}

Ames, B. N. and Shigenaga, M.K. 1992. Oxidants are a major contributor to aging. Ann. N.Y. Acad. Sci., 663: 85-96.

Atjanasuppat, K., Wongkham, W., Meepowpan, P., Kittakoop, P., Sobhon, P., Bartlett, A. and Whitfield, P.J. 2009. 
In vitro screening for anthelmintic and antitumour activity of ethnomedicinal plants from Thailand. $J$. Ethnopharmacol. 123: 475-482.

Bouzari, S., Oloomi, M. and Azadmanesh, K. 2009. Study on induction of apoptosis on HeLa and Vero cells by recombinant Shiga toxin and its subunits. Cytotechnology, 60(1-3): 105-113.

Bunea, A., Rugina, D., Sconta, Z., Pop, R.M., Pintea, A., Socaciu, C., Tabaran, F., Grootaert, C., Struijs, K. and VanCamp, J. 2013. Anthocyanin determination in blueberry extracts from various cultivars and their proliferative and apoptotic properties in B16-F10 metastatic murine melanoma cells. Phytochem. 95: 436-444.

Gollop, R., Even, S., Tsolova, V. and Perl, A. 2002. Expression of the grape dihydroflavonol reductase gene and analysis of its promoter region. J. Exp. Bot., 53(373): 1397-1409.

Haggar, F.A. and Boushey, R.P. 2009. Colorectal cancer epidemiology: incidence, mortality, survival and risk factors. Clin. Colon Rectal. Surg., 22(4): 191-197.

Ji, L., Zhong, B., Jiang, X., Mao, F., Liu, G., Song, B., Wang, C.Y., Jiao, Y., Wang, J.P., Xu, Z.B., Li, X. and Zhan, B. 2017. Actein induces autophagy and apoptosis in human bladder cancer by potentiating ROS/JNK and inhibiting AKT pathways. Oncotarget, 8(68): 112498112515.

Klaunig, J.E. and Kamendulis, L.M. 2004. The role of oxidative stress in carcinogenesis. Ann. Rev. Pharmacol. Toxicol., 44(10): 239-67.

Lazze, M.C., Savio, M., Pizzala, R., Cazzalini, O., Perucca, P., Scovassi, A.I., Stivala, L.A. and Bianchi, L. 2004. Anthocyanins induce cell cycle perturbations and apoptosis in different human cell lines. Carcinogenesis, 25(8): 1427-1433.

Madanakumar, A.J. and Kumaraswamy, M. 2018. Purified anthocyanin, its elicitation from cell cultures of Begonia malabarica and Begonia rex-cultorum 'Baby Rainbow' and its in vitro cytotoxicity analysis by MTT assay. Pharmacogn, J, 10(3): 553-5558.

Oancea, S. and Oprean 2011. Anthocyanins, from biosynthesis in plants to human health benefits-review. Food Technol., 15(1): 3-16.

Olsson, M.E., Gustavsson, K.E., Andersson, S., Nilsson, A. and Duan, R.D. 2004. Inhibition of cancer cell proliferation in vitro by fruit and berry extracts and correlations with antioxidant levels. $J$. Agric. Food Chem., 52(24):7264-7271.

Pervaiz, T., Songtoa, J., Faghihi, F. and Fang, F. 2017. Naturally occurring anthocyanin, structure, functions and biosynthetic pathway in fruit plants. $J$. Plant Biochem. Physiol., 5(2): 187-196.

Reddivari, L., Vanamala, J., Chintharlapalli, S., Safe, S.H. and Miller, J.C. 2007. Anthocyanin fraction from potato extracts is cytotoxic to prostate cancer cells through activation of caspasedependent and caspase-independent pathways. Carcinogenesis, 28(10): 2227-2235.

Rodrigo, K.A., Rawal, Y., Renner, R.J., Schwartz, S.J., Tian, Q., Larsen, P.E. and Mallery, S.R. 2006. Suppression of the tumorigenic phenotype in human oral squamous cell carcinoma cells by an ethanol extract derived from freezedried black raspberries. Nutr. Cancer, 54(1): 58-68.

Rugina, D., Sconta, Z., Leopold, L., Pintea, A., Bunea, A. and Socaciu, C. 2012. Antioxidant activities of chokeberry extracts and the cytotoxic action of their anthocyanin fraction on HeLa human 
cervical tumar cells, J. Med. Food, 15(8): 700-706.

Rugina, D., Hangana, D., Diaconeasa, Z., Tabaran, F., Coman, C., Leopold, L., Bunea, A. and Pintea, A. 2017. Antiproliferative and apoptotic potential of cyaniding-based anthocyanins on melanoma cells. Int. J. Mole. Sci., 18: 949-960.

Wang, D. and Liu, P. 2018. Ingenol-3angelate suppress the growth of melanoma cells and skin tumor development by downregulation of NF${ }_{\mathrm{K}} \mathrm{B}-\mathrm{Cox} 2$ Signaling. Med. Sci. Monit., 24: 486-502.

\section{How to cite this article:}

Suman, R., K. Kalaimathi, R. Suman, S. Palanichamy, R. Sowmiya, M. Mayil Vaganan, I. Ravi and Uma, S. 2018. Anti-cancerous Activities of Anthocyanins of Banana cv. Nendran (Musa sp.) Flower Bracts against Human Colon and Cervical Cancer Cell Lines. Int.J.Curr.Microbiol.App.Sci. 7(12): 2786-2793. doi: https://doi.org/10.20546/ijcmas.2018.712.316 